\title{
Long-term growth rates of four Mediterranean cold-water coral species maintained in aquaria
}

\author{
C. Orejas ${ }^{1,3, *}$, C. Ferrier-Pagès ${ }^{2}$, S. Reynaud ${ }^{2}$, A. Gori ${ }^{1}$, E. Beraud ${ }^{2}$, G. Tsounis ${ }^{1}$, \\ D. Allemand ${ }^{2}$, J. M. Gili ${ }^{1}$
}

${ }^{1}$ Instituto de Ciencias del Mar (CSIC), Pg. Maritim de la Barceloneta 37-49, 08003 Barcelona, Spain

${ }^{2}$ Centre Scientifique de Monaco, Avenue St Martin, 98000 Monaco

${ }^{3}$ Present address: Instituto Español de Oceanografía. Centro Oceanográfico de Santander, Promontorio de San Martín s/n, 39004 Santander, Spain

\begin{abstract}
Growth rates of the cold-water corals (CWC) Madrepora oculata, Lophelia pertusa, Desmophyllum dianthus and Dendrophyllia cornigera were measured over 8 mo under controlled conditions $\left(12^{\circ} \mathrm{C}\right.$ in the dark, fed 5 times a week) by means of the buoyant weight technique. Additionally, linear growth rates were measured in $M$. oculata and $L$. pertusa for 2 and $1 \mathrm{yr}$, respectively. The weight measurements revealed growth rates, expressed as percent growth per day (mean $\pm \mathrm{SD}$ ), of $0.11 \pm 0.04$ for $M$. oculata, $0.02 \pm 0.01$ for $L$. pertusa, $0.06 \pm 0.03$ for D. dianthus and $0.04 \pm 0.02 \%$ $\mathrm{d}^{-1}$ for $D$. cornigera. Growth in $M$. oculata was significantly higher $(\mathrm{p}<0.0001)$ than in the other 3 CWC species. For M. oculata and L. pertusa, also linear growth was recorded. These values (mean \pm $\mathrm{SD}$ ) were $0.014 \pm 0.007$ and $0.024 \pm 0.018 \mathrm{~mm} \mathrm{~d}^{-1}$ for $M$. oculata and L. pertusa, respectively. This is the first study that compares the growth rates of 4 different CWC species under the same experimental conditions of water flow, temperature, salinity and food supply. These corals have different growth rates, both in terms of total weight increase and linear increase, and these growth rates can be related to interspecific physiological differences. Data on growth rates are essential to understand the population dynamics of CWC as well as the recovery capacity of these communities after disturbance.
\end{abstract}

KEY WORDS: Madrepora oculata $\cdot$ Lophelia pertusa $\cdot$ Desmophyllum dianthus $\cdot$ Dendrophyllia cornigera $\cdot$ Buoyant weight $\cdot$ Linear growth $\cdot$ Branching patterns $\cdot$ Mediterranean Sea

\section{INTRODUCTION}

Growth rates of tropical coral species have been widely studied both in situ (e.g. Bongiorni et al. 2003, De'ath et al. 2009) and under controlled laboratory conditions, which has allowed single environmental variables on skeletal growth to be assessed (Buddemeier \& Kinzie 1976, Tambutté et al. 1995, Reynaud et al. 2002, Houlbrèque et al. 2009). In contrast to their tropical congeners, growth rates of cold-water corals (CWC) and the factors influencing their growth have been much less studied owing to the difficulty in accessing their habitats. The abundance, distribution and growth of CWC may be strongly influenced by several biotic and abiotic factors such as food supply, turbidity, temperature, hydrography and ocean chemistry (Cairns \& Parker 1992, Guinotte et al. 2006, Thiem et al. 2006, White et al. 2007, Roberts et al. 2009). In the last $15 \mathrm{yr}$, technological advances facilitated access to deep-water ecosystems that harbour CWC communities. Remotely operated vehicles (ROVs) and manned submersibles equipped with manipulators assist in the photography and recording of these communities, as well as in sample collection. Several recent studies, such as those performed on Gerardia sp. and bamboo corals, have assessed the growth of CWC from the Atlantic and Pacific oceans, as well as the Caribbean Sea (Matsumoto 2007, Andrews et al. 2009, Parrish \& Roark 2009, Thresher 2009) and found very slow growth rates of a few micrometres in radial growth per 
year. However, a higher axial growth rate of 0.5 to $1 \mathrm{~cm}$ $\mathrm{yr}^{-1}$ was estimated for large and old bamboo coral colonies. Other studies on CWC were dedicated to the growth of scleractinian species sampled in the Atlantic and Pacific oceans and the North Sea. The main species studied was Lophelia pertusa, owing to its wide distribution and abundance in the CWC communities of these regions (Teichert 1958, Wilson 1979, Freiwald et al. 1997, Mortensen \& Rapp 1998, Gass \& Roberts 2006, Orejas et al. 2008, Brooke \& Young 2009). The linear extension rate of this species was estimated to range from 5 to $34 \mathrm{~mm} \mathrm{yr}^{-1}$ (reviewed in Roberts et al. 2009). Some other scleractinian species, such as Desmophyllum dianthus, Oculina varicosa and Enallopsammia rostrata were also studied (Boerboom et al. 1998, Cheng et al. 2000, Risk et al. 2002, 2005, Adkins et al. 2004, Houlbrèque et al. 2010). Similar to the octocorals cited above, these scleractinians present very low radial growth rates of a few micrometres per year. A summary of growth rates from different species (including scleractinians, octocorals and antipatharians) measured with different methods has also recently been published (Roberts et al. 2009). These results generally show that growth rate estimates are extremely variable in conjunction with habitat diversity (including depth) of collection sites; this suggests that more data are needed to accurately predict CWC growth.

In contrast to the CWC of the Atlantic and Pacific oceans and the North Sea, Mediterranean cold-water scleractinian corals have received much less attention. They are, however, very abundant in locations of the central and northwestern Mediterranean Sea (e.g. Taviani et al. 2005, Freiwald et al. 2009, Orejas et al. 2009), as reported during the first quantitative surveys (Orejas et al. 2009). Although it remains to be confirmed, these CWC are most likely living at the upper limits of their thermal tolerance $\left(12\right.$ to $\left.14^{\circ} \mathrm{C}\right)$ because the Mediterranean Sea is warmer than all other studied sites where CWC have been recorded (e.g. Norwegian margin and northern, eastern and western Atlantic Ocean). To date, only 2 studies that used different methodologies, including linear growth measurements and calcification rates, have assessed the growth rates of Lophelia pertusa and Madrepora oculata under laboratory conditions (Orejas et al. 2008, Maier et al. 2009). In this study, we compare the growth of 4 Mediterranean scleractinian CWC species (M. oculata, L. pertusa, Desmophyllum dianthus and Dendrophyllia cornigera) maintained in aquaria under the same controlled conditions. Growth rates were measured by means of (1) the buoyant weight technique (Jokiel et al. 1978, Davies 1989) for the 4 species and (2) the linear extension rate for M. oculata and L. pertusa. To better understand CWC biology and ecology, we consider the various factors that influence the growth of CWC species in comparison with their tropical relatives. Considering the major role of CWC as ecosystem engineers in vulnerable marine ecosystems (VME) (Freiwald et al. 2004), this study presents crucial results that can be used to assess their growth rates, which is important to better understand the dynamics of these populations. Additionally, we may learn more about the recovery time of CWC communities after disturbances of natural or anthropogenic origin.

\section{MATERIALS AND METHODS}

Study species. Madrepora oculata forms fragile fanshaped colonies 30 to $50 \mathrm{~cm}$ in height and small polyps 3 to $5 \mathrm{~mm}$ in diameter (Fig. 1a). M. oculata can be found in water as shallow as $55 \mathrm{~m}$ off the coast of Brazil and as deep as $1950 \mathrm{~m}$ off the coast of Iceland (Zibrowius 1980). Lophelia pertusa is also a branched coral that grows to a size of more than $130 \mathrm{~cm}$ (Gass \& Roberts 2006) and forms reefs as high as $33 \mathrm{~m}$ (Mortensen et al. 2001). L. pertusa polyps measure $\sim 5$ to $15 \mathrm{~mm}$ in height and $\sim 1 \mathrm{~cm}$ in diameter (Fig. 1b). This species dwells mostly between 100 and $400 \mathrm{~m}$ depth but has also been found at depths of 40 to $3000 \mathrm{~m}$ (Zibrowius 1980, Cairns 1994, Freiwald 1998, Fosså et al. 2002). Desmophyllum dianthus (Esper 1794) (known in the Mediterranean as D. cristagalli Milne Edwards \& Haime 1848) forms solitary polyps of 5 to $10 \mathrm{~cm}$ height and 1.5 to $3 \mathrm{~cm}$ in diameter (Fig. 1c) and lives between 100 and $4000 \mathrm{~m}$ depth (Risk et al. 2002). Dendrophyllia cornigera forms colonies $15 \mathrm{~cm}$ high with large polyps 2 to $4 \mathrm{~cm}$ in diameter (Fig. 1d) and can be found between 200 to $800 \mathrm{~m}$ deep but locally as shallow as $30 \mathrm{~m}$ (Castric-Fey 1996).

Species collection. Madrepora oculata and Dendrophyllia cornigera colonies were collected in the Cap de Creus canyon (NW Mediterranean Sea) from $250 \mathrm{~m}$ depth and placed on board the RV 'García del Cid' during the cruises 'Deep Coral I_Coral4' and 'HERMES IV_Coral8' in July 2006 and September 2007, respectively. Lophelia pertusa and Desmophyllum dianthus were collected off the Island of Malta at $300 \mathrm{~m}$ depth in September 2007 and placed on board the RV 'Urania' during the cruise 'MARCOS'. Samples were collected and returned to the 'García del Cid' by means of the ROV PHANTOM HD2 + 2 and the manned submersible JAGO (IFM-GEOMAR, Kiel, Germany), whereas samples returned to the 'Urania' were collected by means of an epibenthic sledge.

Growth rate measurements using the buoyant weight technique. Ten colonies of Madrepora oculata, 8 of Lophelia pertusa, 8 of Desmophyllum dianthus and 

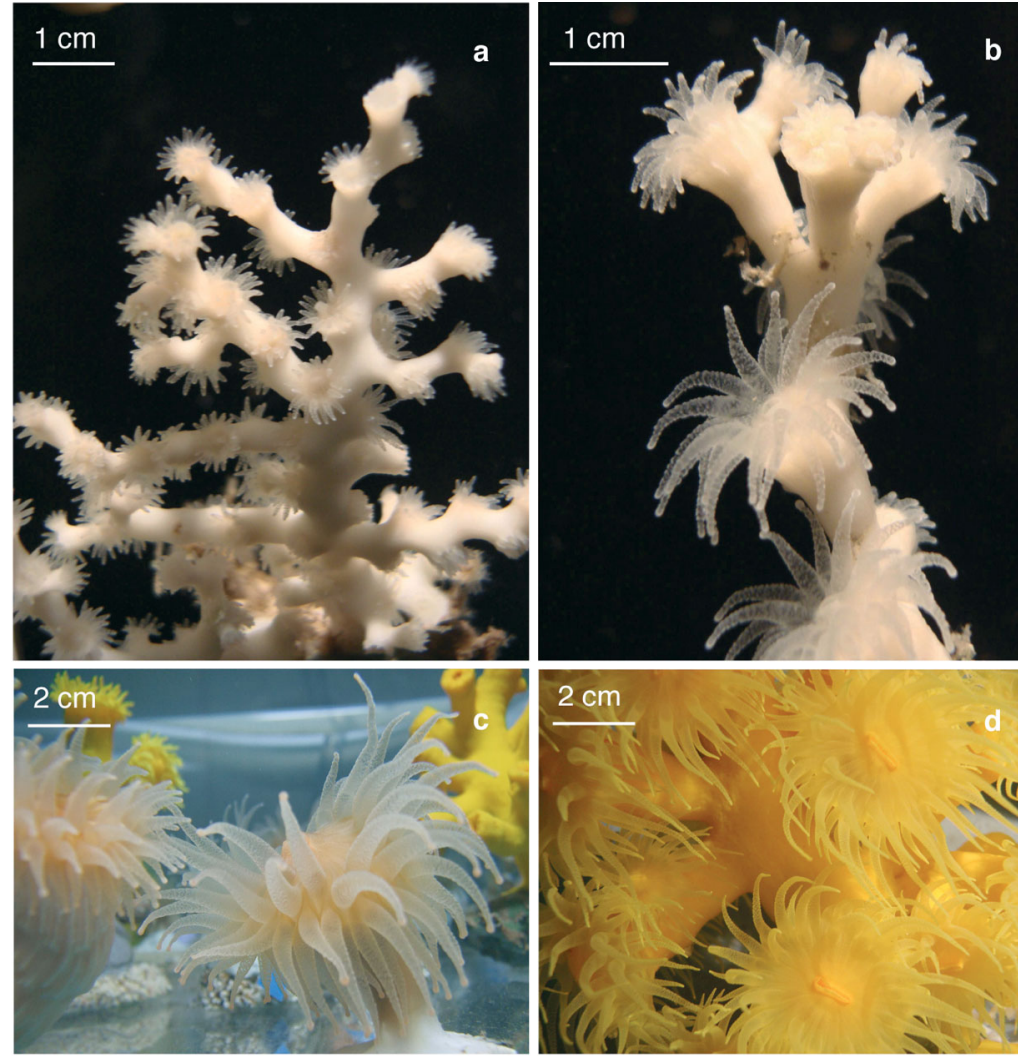

Fig. 1. (a) Madrepora oculata, (b) Lophelia pertusa, (c) Desmophyllum dianthus and (d) Dendrophyllia cornigera. Photos of studied specimens al. 1978, Davies 1989) and an analytical balance (Mettler, model AT 261; precision $0.1 \mathrm{mg}$ ). This technique has been widely used with tropical and temperate corals (e.g. Coles \& Jokiel 1978, RodolfoMetalpa et al. 1999) and consists of determining the dry weight of the skeleton from its weight in seawater based on Archimede's Principle, which accounts for the density of the coral skeleton and the density of seawater (Davies 1989). We also estimated, with the method of Davies (1989), that the buoyant weight of the tissue accounted for 3 to $4 \%$ of the skeletal buoyant weight, which was used to produce a correction factor.

After 3 wk of acclimation 9 measurements were taken: for Madrepora oculata at Times 0, $1(+27 \mathrm{~d}), 2(+62 \mathrm{~d}), 3(+86 \mathrm{~d})$, $4(+107 \mathrm{~d}), 5(+146 \mathrm{~d}), 6(+174 \mathrm{~d}), 7$ $(+209 \mathrm{~d})$ and $8(+244 \mathrm{~d})$, and for the other 3 CWC species (Lophelia pertusa, Desmophyllum dianthus and Dendrophyllia cornigera) at Times $0,1(+21 \mathrm{~d}), 2(+56 \mathrm{~d})$, $3(+80 \mathrm{~d}), 4 \quad(+101 \mathrm{~d}), 5(+140 \mathrm{~d}), 6$ $(+168 \mathrm{~d}), 7(+203 \mathrm{~d})$ and $8(+238 \mathrm{~d})$.

Growth $\left(G_{t}\right)$ was expressed in percentages of daily weight increase as follows:

$$
\mathrm{G}_{t}=100 \times \frac{\mathrm{M}_{t+1}-\mathrm{M}_{t}}{\mathrm{M}_{t}\left(\mathrm{~T}_{t+1}-\mathrm{T}_{t}\right)}
$$

where $M_{t}$ and $M_{t+1}$ are the coral weights (mg) at the beginning $\left(T_{t}\right)$ and the end $\left(T_{t+1}\right)$ of each growth interval. Growth is expressed as percent increase per day $\left(\% \mathrm{~d}^{-1}\right)$. To detect possible differences in growth among the 4 species with optimal precision, a linear regression of the natural logarithm of coral nubbin biomass (mg) versus the experimental time (d) was calculated. The slopes of the regression lines represent the growth rates and were compared with 1-way ANOVA. Owing to the unequal number of specimens for each coral species, the harmonic mean was used to estimate ' $n$ ' in the Student-Newman-Keuls post hoc test.

Growth rate measurement using the linear growth. Seventeen colonies of Madrepora oculata and 10 of Lophelia pertusa were maintained in a $40 \mathrm{ltank}$ with a continuous flow of Mediterranean seawater pumped from $15 \mathrm{~m}$ depth at a rate of $5 \mathrm{l} \mathrm{h}^{-1}$ and filtered by a $50 \mu \mathrm{m}$ sand filter. Two submersible pumps (MAREA 3200) provided continuous water movement in each tank with a flow rate of $3200 \mathrm{l} \mathrm{h}^{-1}$. The water was maintained under the same temperature $\left(12^{\circ} \mathrm{C}\right)$ as mentioned above (Olariaga et al. 2009). Corals were fed 5 times a week as above, with frozen cyclops (to conditions and the skeletal growth rate was assessed
by means of the buoyant weight technique (Jokiel et gastrovascular cavity.

From October 2008 to June 2009, the 4 coral species were maintained for $250 \mathrm{~d}$ under the above controlled 
M. oculata) and mysidacea Artemia salina adults (to L. pertusa). The solitary polyps of Desmophyllum dianthus, as well as the large size and growth structure of Dendrophyllia cornigera colonies, did not permit us to determine their linear growth. From December 2006 to December 2008, linear growth measurements were made with the colonies of M. oculata over $729 \mathrm{~d}$, and of L. pertusa over $391 \mathrm{~d}$. For each $M$. oculata colony, 8 photographs were taken at Times 0, $1(+88 \mathrm{~d}), 2(+162 \mathrm{~d}), 3(+338 \mathrm{~d}), 4(+437$ d), $5(+528 \mathrm{~d}), 6(+631 \mathrm{~d})$ and $7(+729 \mathrm{~d})$, whereas for L. pertusa, measurements started at Time 3. Photos were always taken at the same distance and with the same angle. A photoseries for an $M$. oculata colony is presented in Fig. 2. Linear growth $\left(\mathrm{mm} \mathrm{d}^{-1}\right)$ was measured on branches located in the same plane of the photograph with CARNOY 2.1 software (Schols \& Smets 2001). To calibrate the images we used a ruler (shown in Fig. 2).

Linear specific growth rates were calculated as the slopes of the regression lines relating the coral nubbins' linear extensions $(\mathrm{mm})$ versus the experimental time (d). Results were expressed as linear specific growth rates per day $\left(\mathrm{mm} \mathrm{d}^{-1}\right)$. Slopes of the regression lines were compared to look for statistically significant differences between linear growth rates of the different species via an unpaired $t$-test. Moreover, as a further parameter describing the linear extension of the coral nubbins, the increase in the number of polyps for each nubbin was recorded over the same time period; the mean increase in polyp number per day was calculated for each species following the same method described above.

\section{RESULTS}

\section{Buoyant weight}

The growth rates obtained for the 4 species were $($ mean $\pm \mathrm{SD}): 0.11 \pm 0.04 \% \mathrm{~d}^{-1}$ for Madrepora oculata, $0.02 \pm 0.01 \% \mathrm{~d}^{-1}$ for Lophelia pertusa, $0.06 \pm$ $0.03 \% \mathrm{~d}^{-1}$ for Desmophyllum dianthus and $0.04 \pm$ $0.02 \% \mathrm{~d}^{-1}$ for Dendrophyllia cornigera, with a higher growth rate for $M$. oculata compared with the growth rates of the 3 other CWC species (Fig. 3). The ANOVA of the slopes of the linear regression (growth rates) revealed significant differences $(\mathrm{p}<$ 0.0001 ) between $M$. oculata and the other 3 species (Table 1).

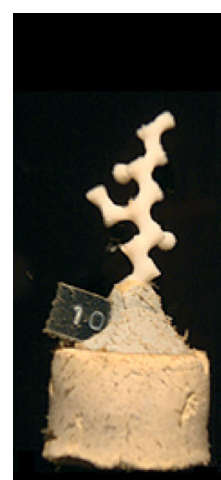

\section{Dec 2006}

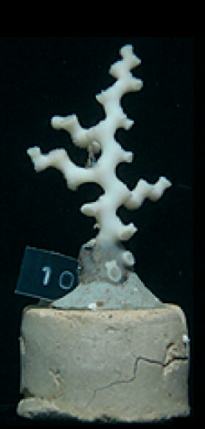

Feb 2008
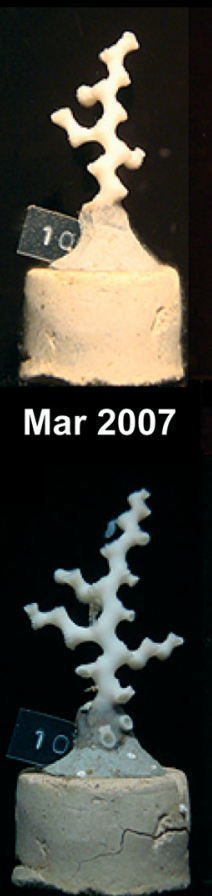

May 2008
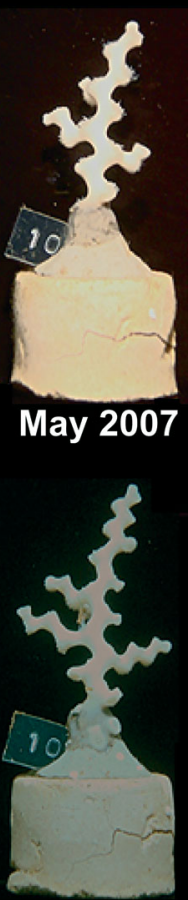

Sep 2008
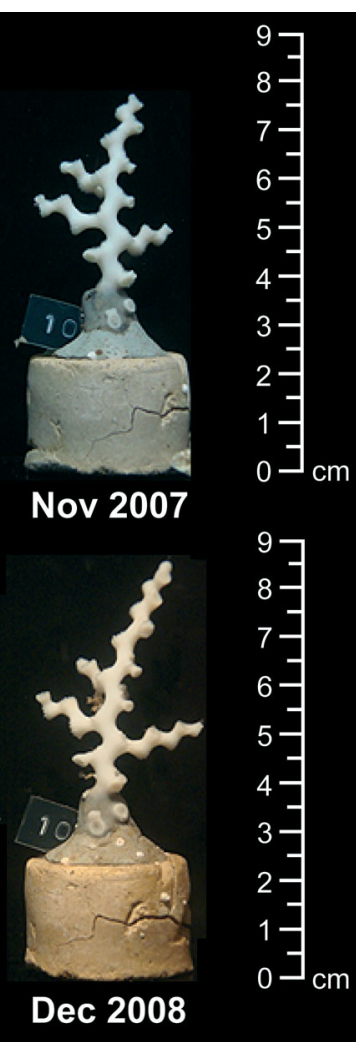

Fig. 2. Madrepora oculata. Photographic series of the linear growth of one of the measured nubbins

\section{Linear growth}

The linear growth rates (mean $\pm \mathrm{SD}$; $\mathrm{mm} \mathrm{d}^{-1}$ ) of Madrepora oculata and Lophelia pertusa were $0.014 \pm 0.007$ and $0.024 \pm 0.018 \mathrm{~mm} \mathrm{~d}^{-1}$, respectively (Fig. 3). The variability between the different nubbins was very high for both species; $M$. oculata presented minimum and maximum growth rates of 0.003 and $0.026 \mathrm{~mm} \mathrm{~d}^{-1}$, respectively, whereas $L$. pertusa presented minimum values of $0.008 \mathrm{~mm} \mathrm{~d}^{-1}$ and maxima of $0.058 \mathrm{~mm}$ $\mathrm{d}^{-1}$. The unpaired $t$-test revealed no significant difference $(p>0.05)$ between the linear growth rates of $M$. oculata and $L$. pertusa.

Polyp number (always means \pm SD) for Madrepora oculata presented a high variability between the different nubbins (6.2 \pm 4.2 polyps per nubbin) and was associated with the different sizes of the nubbins. Polyp number increased from $6.2 \pm 4.2$ polyps per nubbin at the beginning to $10.9 \pm 4.8$ at the end of the experiment. The mean rate of polyp addition was $0.0075 \pm 0.0038$ polyps $\mathrm{d}^{-1}$, which corresponds to a mean of one new 


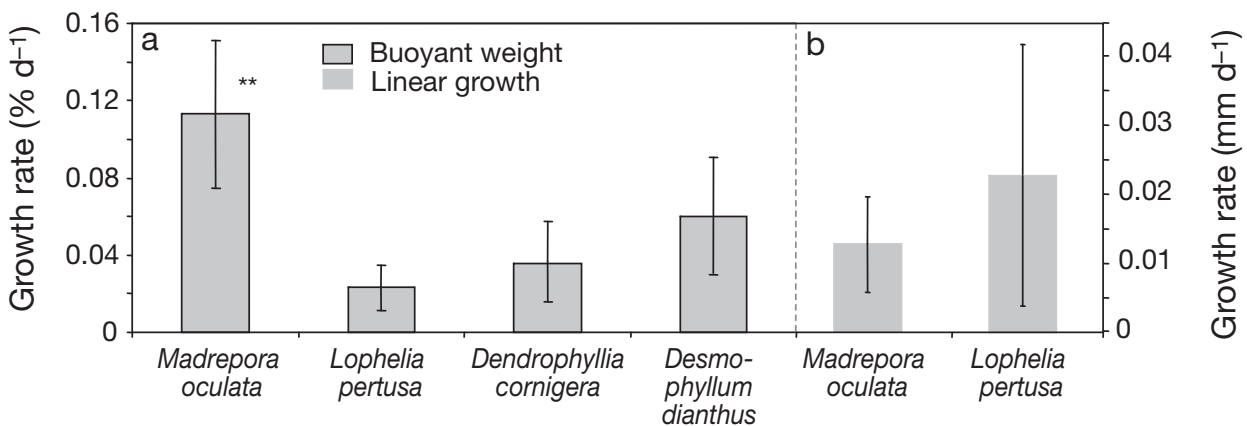

Fig. 3. (a) Madrepora oculata, Lophelia pertusa, Desmophyllum dianthus and Dendrophyllia cornigera. Growth rates $\left(\% \mathrm{~d}^{-1}\right.$, mean $\pm \mathrm{SD}$ ) for each CWC species after the buoyant weight measurements. (b) Madrepora oculata and Lophelia pertusa. Growth rates $\left(\mathrm{mm} \mathrm{d}^{-1}\right.$, mean $\left.\pm \mathrm{SD}\right)$ for each $\mathrm{CWC}$ species after the linear growth measurements. ${ }^{* *} \mathrm{p}<0.0001$

Table 1. Madrepora oculata, Lophelia pertusa, Desmophyllum dianthus and Dendrophyllia cornigera. (a) ANOVA for growth rate for the 4 CWC species. (b) Student-NewmanKeuls post hoc tests comparing species growth rates. ${ }^{*} \mathrm{p}<0.0001$

\begin{tabular}{|c|c|c|c|c|c|}
\hline $\begin{array}{l}\text { (a) } \\
\text { Species }\end{array}$ & df & \multicolumn{2}{|c|}{ Sum of squares } & $F$ & $\mathrm{p}$ \\
\hline Residual & $\begin{array}{c}3 \\
25\end{array}$ & \multicolumn{2}{|c|}{$\begin{array}{l}4.341 \times 10^{-6} \\
1.851 \times 10^{-6}\end{array}$} & 19.541 & $<0.0001$ \\
\hline $\begin{array}{l}\text { (b) } \\
\text { Species }\end{array}$ & & & $\begin{array}{r}\mathrm{M \epsilon} \\
\text { diffe }\end{array}$ & $\begin{array}{l}\text { in } \\
\text { nce }\end{array}$ & $\begin{array}{c}\text { Critical } \\
\text { difference }\end{array}$ \\
\hline \multicolumn{3}{|c|}{ D. cornigera, D. dianthus } & \multicolumn{2}{|c|}{$-4.583 \times 10^{-5}$} & $3.278 \times 10^{-4}$ \\
\hline \multicolumn{3}{|c|}{$D$. cornigera, $L$. pertusa } & \multicolumn{2}{|c|}{$1.354 \times 10^{-4}$} & $3.278 \times 10^{-4}$ \\
\hline \multirow{2}{*}{\multicolumn{3}{|c|}{$\begin{array}{l}\text { D. cornigera, } M \text {. oculata } \\
\text { D. dianthus, L pertusa }\end{array}$}} & \multicolumn{2}{|c|}{-0.001} & $3.963 \times 10^{-4 *}$ \\
\hline & & D. dianthus, L. pertusa & \multicolumn{2}{|c|}{$1.813 \times 10^{-4}$} & $3.963 \times 10^{-4}$ \\
\hline \multicolumn{3}{|c|}{ D. dianthus, M. oculata } & \multicolumn{2}{|c|}{-0.001} & $3.278 \times 10^{-4 *}$ \\
\hline \multicolumn{3}{|c|}{ L. pertusa, M. oculata } & \multicolumn{2}{|c|}{-0.001} & $4.375 \times 10^{-4 *}$ \\
\hline
\end{tabular}

budded polyp every 4 mo. Polyp number for Lophelia pertusa was also variable among nubbins for the same reason. The number increased from $2.9 \pm 1.1$ polyps per nubbin at the beginning to $4.2 \pm 2.4$ at the end of the experiment. The mean rate of polyp addition was $0.0037 \pm 0.0043$ polyps $\mathrm{d}^{-1}$, which corresponds to 1 new polyp budded after $\sim 7$ mo.

\section{DISCUSSION}

Results obtained from the buoyant weight measurements show a high variability in growth rates between and within the CWC species. This variability has been recorded by Brooke \& Young (2009) in an in situ experiment with Lophelia pertusa, which presented a high variability between the different nubbins used for that experiment. Additionally, the great plasticity of colony morphology observed in L. pertusa (Cairns 1979, Brooke \& Schroeder 2007, Roberts et al. 2009) suggests that growth of this species is naturally highly variable, which could also be the case for the other CWC species in this study.

Because all species have been maintained in aquaria under exactly the same conditions, the significant differences observed between the growth rate of Madrepora oculata and the other 3 species are not due to differences in environmental factors, but rather due to interspecific differences in their physiology. High growth rates might be due to the branched form of $M$. oculata, which is more ramified than the other CWC. It is known that calcification rates in tropical corals are higher in branched than in massive species (Goreau \& Goreau 1959), as different skeletal structures and shapes of colonies lead to different rates of carbonate deposition (Goreau \& Goreau 1959, Schlöder \& D'Croz 2004). Acropora, one of the most ramified genus among tropical corals, also grows faster than other branched corals (Sorokin 1995). Additionally, the 4 CWC species differ in the number of polyps per skeletal surface area owing to the different size of the polyps. M. oculata colonies have the highest polyp density (Fig. 1) and a higher rate of polyp budding than do Lophelia pertusa colonies. These differences may increase the efficiency of prey capture and energy input in the coral tissue as shown in tropical corals (Anthony 2000, Anthony \& Fabricius 2000, Ferrier-Pagès et al. 2003, Palardy et al. 2005, 2008); therefore, they have a positive effect on the growth rates. Factors that influence growth rates include food availability and quality. Because energy allocation in corals is divided into tissue and skeletal growth (Anthony et al. 2002), the small size of the M. oculata polyps compared with the other 3 CWC species suggests that more energy is allocated to the growth of the skeleton. Conversely, L. pertusa, Desmophyllum dianthus and Dendrophyllia cornigera have larger 
polyps, so they build more soft tissue and may in turn allocate less energy to skeletal growth (Anthony et al. 2002). In the case of $L$. pertusa, Mortensen (2000) suggested that linear growth is correlated with seasonal temperature variations, but also noted that temperature may covary with other factors such as food supply. Thus, aquarium studies of this species in Norway and Scotland (Mortensen 2001, Roberts \& Anderson 2002) indicated that increased food supply was followed by high extension rates. Therefore, seasonal changes in food supply, rather than temperature, may control growth rates of $L$. pertusa in the field.

Furthermore, different skeletal microstructures highly influence coral growth rates (Nothdurft \& Webb 2007), which could explain the distinct growth rates observed among species considering the different results were obtained through 2 different measuring methods. Even if there is some information on the skeletal microstructure of CWC species, this has been studied in order to explore its use as palaeoarchives (e.g. Blamart et al. 2007, Montagna et al. 2008) and not as a tool to interpret ecological or ecophysiological studies. To our knowledge, no studies have been conducted to investigate the possible relationships between growth and corallite microstructure. These data would greatly improve our understanding of CWC growth rates and corals in general.

Temperature is known to be an important factor affecting the growth rate of tropical, temperate (e.g. Buddemeier \& Kinzie 1976, Lough \& Barnes 1997, 2000, Bessat \& Buigues 2001, Howe \& Marshall 2002, McNeil et al. 2004, Allemand et al. 2010) and coldwater corals (Matsumoto 2007) with a thermal adaptation of the different coral species (Clausen 1971, Clausen \& Roth 1975, Rodolfo-Metalpa et al. 2008). Consequently, it is highly likely that CWC have adapted to lower temperatures, even though the optimum and critical temperatures for CWC species still need to be determined. Nevertheless, analyses of fossilized coral (Wienberg et al. 2009) as well as recent studies (Keller \& Os'kina 2008) have shown that Madrepora oculata appears to be more tolerant to a wide range of changing environmental conditions than other species. The higher temperature tolerance of M. oculata may explain the observed 'faster' growth, possibly owing to better adaptation to the current 'warm' Mediterranean conditions (in relation to its geological history, especially before the Holocene sea level rise) when Lophelia pertusa and Dendrophyllia cornigera were better adapted to the cooler temperatures (Wienberg et al. 2009). Furthermore, previous experiments comparing growth rates of tropical coral versus a CWC species reported similar rates for the zooxanthellate coral Galaxea fascicularis and the CWC M. oculata despite a $15^{\circ} \mathrm{C}$ temperature difference
(Orejas et al. in press). This could confirm a considerably faster relative growth rate of $M$. oculata if it is located within warmer waters. Studies on CWC growth rates are vital to increase our knowledge of population dynamics of these organisms, as well as to predict the recovery time of CWC communities after disturbances. Indeed, the gaps in our knowledge of growth rates also limit our understanding of palaeo records when confronted with current and future threats, such as bottom trawling and global climate change (Roberts et al. 2009).

Further research is clearly needed to improve our knowledge on the factors that drive CWC growth patterns, especially in future scenarios where seawater acidification plays an important role in coral growth. This role has been shown experimentally by several authors at the organism level (Marubini \& Atkinson 1999, Marubini et al. 2001, 2003, 2008, Schneider \& Erez 2006) and the community level (Langdon 2000, Leclercq et al. 2000, Langdon et al. 2003).

Acknowledgements. The authors thank C. Rottier for help in the laboratory and A. Olariaga, B. Vendrell, X. Leal, M. Dalmau, F. X. Capdevila and L. Pedret for helping with the coral care. Thanks to L. Yebra for help with the statistical approach. This work was funded by the European Projects HERMES (Goce-CT-2005-511234-I) and HERMIONE (Grant Agreement Number 226354) and the Spanish Project DEEP CORAL (CTM2005-07756-C02-02/MAR). This collaborative study was also partly supported by the Government of the Principality of Monaco. C. Orejas was supported by a I3P postdoctoral contract from Consejo Superior de Investigaciones Científicas, CSIC (I3P-PC2006L), co-financed by the European Social Fund, and G. Tsounis by a postdoctoral fellowship by the Spanish Ministry for Science and Innovation (E-08-20071673618). We are indebted to the crew of the RV 'García del Cid' and the 'Urania'. Thanks also go to the JAGO-team, J. Schauer and K. Hissmann (Leibniz-Institut für Meereswissenschaften IFM-GEOMAR, Kiel, Germany). Thanks are extended to M. Taviani for supporting maintenance of living corals on board the 'Urania', P. Montagna for help in maintaining the live corals on board and the 3 anonymous referees for their thoughtful comments.

\section{LITERATURE CITED}

Adkins JF, Henderson GM, Wang SL, O'Shea S, Mokadem F (2004) Growth rates of the deep-sea scleractinia Desmophyllum cristagalli and Enallopsammia rostrata. Earth Planet Sci Lett 227:481-490

Allemand D, Tambutté E, Zoccola D, Tambutté S (2010) Coral calcification, cells to reefs. In: Dubinsky Z (ed) Coral reefs Elsevier, Amsterdam, p 1-51

> Andrews AH, Stone RP, Lundstrom CC, DeVogelaere AP (2009) Growth rate and age determination of bamboo corals from the northeastern Pacific Ocean using refined ${ }^{210} \mathrm{~Pb}$ dating. Mar Ecol Prog Ser 397:173-185

Anthony KRN (2000) Enhanced particle-feeding capacity of corals on turbid reefs (Great Barrier Reef, Australia). Coral Reefs 19:59-67

Anthony KRN, Fabricius KE (2000) Shifting roles of heterotro- 
phy and autotrophy in coral energetics under varying turbidity. J Exp Mar Biol Ecol 252:221-253

Anthony KRN, Connolly SR, Willis BL (2002) Comparative analysis of energy allocation to tissue and skeletal growth in corals. Limnol Oceanogr 47:1417-1429

Bessat F, Buigues D (2001) Two centuries of variation in coral growth in a massive Porites colony from Moorea (French Polynesia): a response of ocean-atmosphere variability from south central Pacific. Palaeogeogr Palaeoclimatol Palaeoecol 175:381-392

Blamart D, Rollion-Bard C, Meibom A, Cuif JP, Juillet-Leclerc A, Dauphin Y (2007) Correlation of boron isotopic composition with ultrastructure in the deep-sea coral Lophelia pertusa: implications for biomineralization and paleo-pH. Geochem Geophys Geosyst 8:Q12001. doi:10.1029/ 2007GC001686c

Boerboom CM, Smith JE, Risk MJ (1998) Bioerosion and micritization in the deep-sea coral Desmophyllum cristagalli. Hist Biol 13:53-60

Bongiorni L, Shafir S, Angel D, Rinkevich B (2003) Survival, growth and gonad development of two hermatypic corals subjected to in situ fish-farm nutrient enrichment. Mar Ecol Prog Ser 253:137-144

Brooke S, Schroeder WW (2007) State of deep coral ecosystems in the Gulf of Mexico region: Texas to the Florida Straits. In: Lumsden SE, Hourigan TF, Bruckner AW (eds) The state of deep coral ecosystems of the United States. NOAA Tech Memo NOS-CRCP-3, NOAA, Silver Spring, MD, p 1-64

> Brooke S, Young CM (2009) In situ measurements of survival and growth of Lophelia pertusa in the northern Gulf of Mexico. Mar Ecol Prog Ser 397:153-161

Buddemeier RW, Kinzie RA (1976) Coral growth. Oceanogr Mar Biol Annu Rev 14:183-225

Cairns SD (1979) The deep-water Scleractinia of the Caribbean Sea and adjacent waters. Stud Fauna Curaçao $57: 1-341$

Cairns SD (1994) Scleractinia of the temperate North Pacific. Smithsonian Contributions to Zoology 557, Smithsonian Institution Press, Washington, DC

> Cairns SD, Parker SA (1992) Phylogenetic implications of calcium carbonate mineralogy in the Stylasteridae (Cnidaria: Hydrozoa). Palaios 7:96-107

Castric-Fey A (1996) The scleractinian Dendrophyllia cornigera in shallow water, at Ushant (Brittany, NE Atlantic), related to the absence of a thermic barrier. Oceanol Acta 19:665-671

Cheng H, Adkins J, Edwards RL, Boyle EA (2000) U-Th dating of deep-sea corals. Geochim Cosmochim Acta 64: 2401-2416

Clausen CD (1971) Effects of temperature on the rate of ${ }^{45} \mathrm{Ca}$ uptake by Pocillopora damicornis. In: Lenhoff HM, Muscatine L, Davis LV (eds) Experimental coelenterate biology. University of Hawaii Press, Honolulu, HI, p 246-259

> Clausen CD, Roth AA (1975) Effect of temperature and temperature adaptation on calcification rate in the hermatypic coral Pocillopora damicornis. Mar Biol 33:93-100

Coles SL, Jokiel PL (1978) Synergistic effects of temperature, salinity and light on the hermatypic coral Montipora verrucosa. Mar Biol 49:187-195

Davies PS (1989) Short-term growth measurements of corals using an accurate buoyant weighing technique. Mar Biol 101:389-395

> De'ath G, Lough JM, Fabricius KE (2009) Declining coral calcification on the Great Barrier Reef. Science 323:116-119

> Ferrier-Pagès C, Gattuso JP, Cauwet G, Jaubert J, Allemand D (1998) Release of dissolved organic carbon and nitrogen by the zooxanthellate coral Galaxea fascicularis. Mar Ecol Prog Ser 172:265-274

Ferrier-Pagès C, Witting J, Tambutté E, Sebens KP (2003) Effect of natural zooplankton feeding on the tissue and skeletal growth of the scleractinian coral Stylophora pistillata. Coral Reefs 22:229-240

> Fosså JH, Mortensen PB, Furevik DM (2002) The deep-water coral Lophelia pertusa in Norwegian waters: distribution and fishery impacts. Hydrobiologia 471:1-12

Freiwald A (1998) Geobiology of Lophelia pertusa (Scleractinia) reefs in the north Atlantic. Habilitation thesis, University of Bremen

Freiwald A, Henrich R, Patzold J (1997) Anatomy of a deepwater coral reef mound from Stjernsund, west Finnmark, northern Norway. In: James NP, Clarke JAD (eds) Coolwater carbonates. SEPM Spec Publ 56:141-162

Freiwald A, Fosså JH, Grehan A, Koslow T, Roberts JM (2004) Cold water coral reefs. UN Environ Progr World Conserv Monit Cent (UNEP-WCMC), Cambridge

Freiwald A, Beuck L, Rüggeberg A, Taviani M, Hebbeln D (2009) The white coral community in the Central Mediterranean Sea revealed by ROV surveys. Oceanography 22: $58-74$

Gass SE, Roberts JM (2006) The occurrence of the cold-water coral Lophelia pertusa (Scleractinia) on oil and gas platforms in the North Sea: colony growth, recruitment and environmental controls on distribution. Mar Pollut Bull 52: 549-559

> Goreau TF, Goreau NI (1959) The physiology of skeleton formation in corals. 2. Calcium deposition by hermatypic corals under various conditions in the reef. Biol Bull (Woods Hole) 117:239-250

Guinotte JM, Orr J, Cairns SD (2006) Will human-induced changes in seawater chemistry alter the distribution of deep-sea scleractinian corals? Front Ecol Environ $4: 141-146$

Houlbrèque $\mathrm{F}$, Meibom $\mathrm{A}$, Cuif JP, Stolarski $\mathrm{J}$ and others (2009) Strontium-86 labeling experiments show spatially heterogeneous skeletal formation in the scleractinian coral Porites porites. Geophy Res Lett 36:L04604

> Houlbrèque F, McCulloch M, Roark B, Guilderson T and others (2010) Uranium-series dating and growth characteristics of the deep-sea scleractinian coral: Enallopsammia rostrata from the Equatorial Pacific. Geochim Cosmochim Acta 74:2380-2395

Howe SA, Marshall AT (2002) Temperature effects on calcification rate and skeletal deposition in the temperate coral, Plesiastrea versipora (Lamarck). J Exp Mar Biol Ecol 275: 63-81

Jokiel PL, Maragos JE, Franzisket L (1978) Coral growth: buoyant weight technique. In: Stoddard JR, Johannes RE (eds) Coral reefs: research methods. UNESCO, Paris, p 529-541

Keller NB, Os'kina NS (2008) Habitat temperature ranges of azooxantellate scleractinian corals in the world ocean. Oceanology 48:77-84

Langdon C (2000) Review of experimental evidence for effects for $\mathrm{CO}_{2}$ on calcification of reef builders. Proc 9th Int Coral Reef Symp, Bali 2:1091-1098

Langdon C, Broecker WS, Hammond DE, Glenn E and others (2003) Effect of elevated $\mathrm{CO}_{2}$ on the community metabolism of an experimental coral reef. Glob Biogeochem Cycles 17:L1011

> Leclercq N, Gattuso JP, Jaubert J (2000) $\mathrm{CO}_{2}$ partial pressure controls the calcification rate of a coral community. Glob Change Biol 6:329-334

Lough JM, Barnes DJ (1997) Several centuries of variation in 
skeletal extension, density and calcification in massive Porites colonies from the Great Barrier Reef: a proxy for seawater temperature and a background of variability against which to identify unnatural change. J Exp Mar Biol Ecol 211:29-67

Lough JM, Barnes DJ (2000) Environmental controls on growth of the massive coral Porites. J Exp Mar Biol Ecol 245:225-243

Maier C, Hegeman J, Weinbauer MG, Gattuso JP (2009) Calcification of the cold-water coral Lophelia pertusa under ambient and reduced $\mathrm{pH}$. Biogeosci Discuss 6: 1875-1901

Marubini F, Atkinson MJ (1999) Effects of lowered pH and elevated nitrate on coral calcification. Mar Ecol Prog Ser 188:117-122

Marubini F, Barnett H, Langdon C, Atkinson MJ (2001) Dependence of calcification on light and carbonate ion concentration for the hermatypic coral Porites compressa. Mar Ecol Prog Ser 220:153-162

Marubini F, Ferrier-Pagès C, Cuif JP (2003) Suppression of growth in scleractinian corals by decreasing ambient carbonate ion concentration: a cross-family comparison. Proc R Soc B Biol Sci 270:179-184

Marubini F, Ferrier-Pagès C, Furla P, Allemand D (2008) Coral calcification responds to seawater acidification: a working hypothesis towards a physiological mechanism. Coral Reefs 27:491-499

Matsumoto AK (2007) Effects of low water temperature on growth and magnesium carbonate concentrations in the cold-water gorgonian Primnoa pacifica. Bull Mar Sci 81: 423-435

McNeil B, Matear RJ, Barnes DJ (2004) Coral reef calcification and climate change: the effect of ocean warming. Geophys Res Lett 31:L22309 doi:10.1029/2004GL021541

Montagna P, Correa ML, Rüggeberg A, Dullo WC (2008) Coral $\mathrm{Li} / \mathrm{Ca}$ in microstructural domains as a temperature proxy. Geochim Cosmochim Acta 72:A645

Mortensen PB (2000) Lophelia pertusa (Scleractinia) in Norwegian waters. Distribution, growth, and associated fauna. PhD thesis, University of Bergen

Mortensen PB (2001) Aquarium observations on the deepwater coral Lophelia pertusa (L., 1758) (Scleractinia) and selected associated invertebrates. Ophelia 54:83-104

Mortensen PB, Rapp HT (1998) Oxygen and carbon isotope ratios related to growth line patterns in skeletons of Lophelia pertusa (L) (Anthozoa, Scleractinia): implications for determination of linear extension rates. Sarsia 83: 433-446

Mortensen PB, Hovland MT, Fossa JH, Furevik DM (2001) Distribution, abundance and size of Lophelia pertusa coral reefs in mid-Norway in relation to seabed characteristics. J Mar Biol Assoc UK 81:581-597

Nothdurft LD, Webb GE (2007) Microstructure of common reef-building genera Acropora, Pocillopora, Goniastrea and Porites: constraints on spatial resolution in geochemical sampling. Facies 53:1-26

Olariaga A, Gori A, Orejas C, Gili JM (2009) Development of an autonomous aquarium system for maintaining deep corals. Oceanography 22:44-45

Orejas C, Gori A, Gili JM (2008) Growth rates of live Lophelia pertusa and Madrepora oculata from the Mediterranean Sea maintained in aquaria. Coral Reefs 27:255

Orejas C, Gori A, Lo Iacono C, Puig P, Gili JM, Dale MRT (2009) Cold-water corals in the Cap de Creus canyon, northwestern Mediterranean: spatial distribution, density and anthropogenic impact. Mar Ecol Prog Ser 397:37-51

Orejas C, Ferrier-Pagès C, Reynaud S, Tsounis G and others (in press) Experimental comparison of skeletal growth rates in the cold-water coral Madrepora oculata Linnaeus, 1758 and three tropical scleractinian corals. J Exp Mar Biol Ecol

Palardy JE, Grottoli AG, Matthews KA (2005) Effects of upwelling, depth, morphology and polyp size on feeding in three species of Panamanian corals. Mar Ecol Prog Ser 300:79-89

Palardy JE, Rodrigues LJ, Grottoli AG (2008) The importance of zooplankton to the daily metabolic carbon requirements of healthy and bleached corals at two depths. J Exp Mar Biol Ecol 367:180-188

Parrish FA, Roark EB (2009) Growth validation of gold coral Gerardia sp. in the Hawaiian Archipelago. Mar Ecol Prog Ser 397:163-172

Reynaud S, Ferrier-Pagès C, Sambrotto R, Juillet-Leclerc A, Jaubert J, Gattuso JP (2002) Effect of feeding on the carbon and oxygen isotopic composition in the tissues and skeleton of the zooxanthellate coral Stylophora pistillata. Mar Ecol Prog Ser 238:81-89

> Risk MJ, Heikoop JM, Snow MG, Beukens R (2002) Lifespans and growth pattern of two deep-sea corals: Primnoa resedaeformis and Desmophyllum cristagalli. Hydrobiologia 471:125-131

Risk MJ, Hall-Spencer J, Williams B (2005) Climate records from the Faroe-Shetland Channel using Lophelia pertusa (Linnaeus, 1758). In: Freiwald A, Roberts JM (eds) Coldwater corals and ecosystems. Springer-Verlag, Berlin, p 1097-1108

Roberts JM, Anderson RM (2002) A new laboratory method for monitoring deep-water coral polyp behaviour. In: 1st Int Deep-Sea Coral Symp. Hydrobiologia 471:143-148

Roberts JM, Wheeler A, Freiwald A, Cairns S (2009) Coldwater corals. The biology and geology of deep-sea coral habitats. Cambridge University Press, Cambridge

Rodolfo-Metalpa R, Peirano A, Morri C, Bianchi CN (1999) Coral calcification rates in the Mediterranean scleractinian coral Cladocora caespitosa (L., 1767). Atti Assoc Ital Oceanol Limnol 13:291-299

> Rodolfo-Metalpa R, Peirano A, Houlbrèque F, Abbate $M$, Ferrier-Pagès C (2008) Effects of temperature, light and heterotrophy on the growth rate and budding of the temperate coral Cladocora caespitosa. Coral Reefs 27:17-25

Schlöder C, D'Croz L (2004) Responses of massive and branching coral species to the combined effects of water temperature and nitrate enrichment. J Exp Mar Biol Ecol 313:255-268

> Schneider K, Erez J (2006) The effect of carbonate chemistry on calcification and photosynthesis in the hermatypic coral Acropora eurystoma. Limnol Oceanogr 51: 1284-1293

Schols P, Smets E (2001) Carnoy: analysis software for LM, SEM and TEM images. Leuven (distributed by the authors). www.carnoy.org

Sorokin YI (1995) Coral reef ecology. Ecological studies. Springer, Berlin

- Tambutté E, Allemand D, Bourge I, Gattuso JP, Jaubert J (1995) An improved ${ }^{45} \mathrm{Ca}$ protocol for investigating physiological mechanisms in coral calcification. Mar Biol 122: 453-459

Taviani MA, Freiwald A, Zibrowius H (2005) Deep coral growth in the Mediterranean Sea: an overview. In: Freiwald A, Roberts JM (eds) Cold-water corals and ecosystems. Springer-Verlag, Berlin, p 137-156

> Teichert C (1958) Some biostratigraphical concepts. Geol Soc Am Bull 69:99-119

> Thiem O, Ravagnan E, Fossa JH, Bernsten J (2006) Food supply mechanisms for cold-water corals along a continental 
shelf. J Mar Syst 60:207-219

Thresher RE (2009) Environmental and compositional correlates of growth rate in deep-water bamboo corals (Gorgonacea; Isididae). Mar Ecol Prog Ser 397:187-196

White M, Bashmachnikov I, Aristegui J, Martins A (2007)

Physical processes and seamounts productivity. In: Pitcher TJ, Morato T, Hart PJB (eds) Seamounts: ecology, fisheries and conservation. Blackwell, Oxford, p 65-84

> Wienberg C, Hebbeln D, Fink HG, Mienis F and others (2009)

Editorial responsibility: Karen Miller,

Hobart, Australia
Scleractinian cold-water corals in the Gulf of Cádiz - first clues about their spatial and temporal distribution. DeepSea Res I 56:1873-1893

- Wilson JB (1979) The distribution of the coral Lophelia pertusa (L.) [L. prolifera] in the north-east Atlantic. J Mar Biol Assoc UK 59:149-164

Zibrowius H (1980) Les scléractinies de la Méditerranée et de l'Atlantique nord-oriental. Mem Inst Oceanogr (Monaco) $11: 1-284$

Submitted: July 28, 2010; Accepted: February 23, 2011

Proofs received from author(s): May 4, 2011 